\title{
Distribution and Abundance of Beaked Redfish in the Gulf of St. Lawrence, 1976-81
}

\author{
D. B. Atkinson \\ Department of Fisheries and Oceans, Fisheries Research Branch \\ Northwest Atlantic Fisheries Centre, P. O. Box 5667 \\ St. John's, Newfoundland, Canada A1C 5X1
}

\begin{abstract}
The distribution of beaked redfishes of the genus Sebastes in the Gulf of St. Lawrence was determined from bottom-trawl surveys in summer, autumn and winter during 1976-81. Redfish were found in depths greater than $180 \mathrm{~m}$ where bottom temperatures ranged from $2^{\circ}$ to $7^{\circ} \mathrm{C}$. They were distributed throughout the deepwater areas of the Gulf during summer and early autumn but migrated southward and eastward during autumn and early winter to become concentrated in the southeastern region of the Gulf. Juvenile redfish tended to prefer somewhat shallower depths than adults. Small redfish $(\leqslant 15 \mathrm{~cm})$, indicative of successful year-classes, were found to be concentrated mainly in the nursery area in the northern part of the Esquiman Channel in summer, but, as they became older, they were more dispersed throughout the Gulf.
\end{abstract}

\section{Introduction}

During 1947-50, exploratory trawling by the research vessel Investigator, operating from the St. John's Biological Station, Newfoundland, indicated the presence of an extensive population of redfish (Sebastes sp.) in the deep channels of the Gulf of St. Lawrence (Templeman, 1959). Commercial exploitation began in 1951 and nominal catches increased rapidly to a peak of 50,000 (metric) tons in 1955. After several years of low fishing intensity, catches again increased and exceeded 60,000 tons annually during 1966-75, with a peak catch of 130,000 tons in 1973 (ICNAF, 1957-80). The subsequent rapid decline in catches to about 15,000 tons in 1977-78 and the urgent need for scientific advice on conservation measures resulted in intensification of research vessel surveys during the late 1970's.

Various researchers have described the distribution of redfish in the Gulf of St. Lawrence on the basis of commercial fishing activity and sporadic research vessel operations (Steele, 1957; Templeman, 1959; Bergeron, 1961; Martin, 1961; Koeller and LeGresely, MS 1981). These descriptions either were superficial in nature or dealt with localized areas, and no study to date has examined the annual and seasonal changes in redfish distribution throughout the entire Gulf. Such information is essential for understanding the biology and population dynamics of redfish in the region and for the successful management of the commercial fishery.

Templeman and Sandeman (1957) recognized the existence of two varieties of redfish in the Newfoundland area (mentella-type and marinus-type, which were subsequently called Sebastes mentella and $S$. marinus). Templeman (1959) noted that both types were present in the Gulf of St. Lawrence, the major concentrations consisting of $S$. mentella (beaked redfish). This observation has recently been confirmed by $\mathrm{Ni}$ and McKone (1983). Ni (1982) has shown that beaked redfish of the Northwest Atlantic are composed of two species, S. mentella and S. fasciatus, and that the two species occur in the Gulf of St. Lawrence, but separation can only be achieved through dissection (Ni, 1981) or biochemical techniques (Payne and $\mathrm{Ni}$, 1982). Because the existence of the two species was unknown at the time of the surveys in 1976-81, this paper deals with the distribution and abundance of beaked redfishes (hereinafter referred to as redfish) in the Gulf of St. Lawrence.

\section{Materials and Methods}

The study area (Fig. 1) includes all depths where redfish are found throughout the Gulf of St. Lawrence. The summer (July-August) surveys in 1976 and 1978-81 were conducted with a Yankee No. 36 shrimp trawl according to the stratification scheme (described briefly by Atkinson, 1984) which was originally designed for shrimp surveys. The autumn (SeptemberOctober) surveys in 1977-80 were conducted with a Yankee No. 41.5 otter trawl and the winter surveys (January-February) in 1978-81 with an Engels highrise otter trawl. These surveys were carried out according to the standard stratified-random design for groundfish surveys in the Gulf of St. Lawrence (Doubleday, 1981). All tows were typically of 30-min duration at a speed of 3.5 knots $(108 \mathrm{~m} / \mathrm{min})$. Additional information on the surveys is listed in Table 1. 


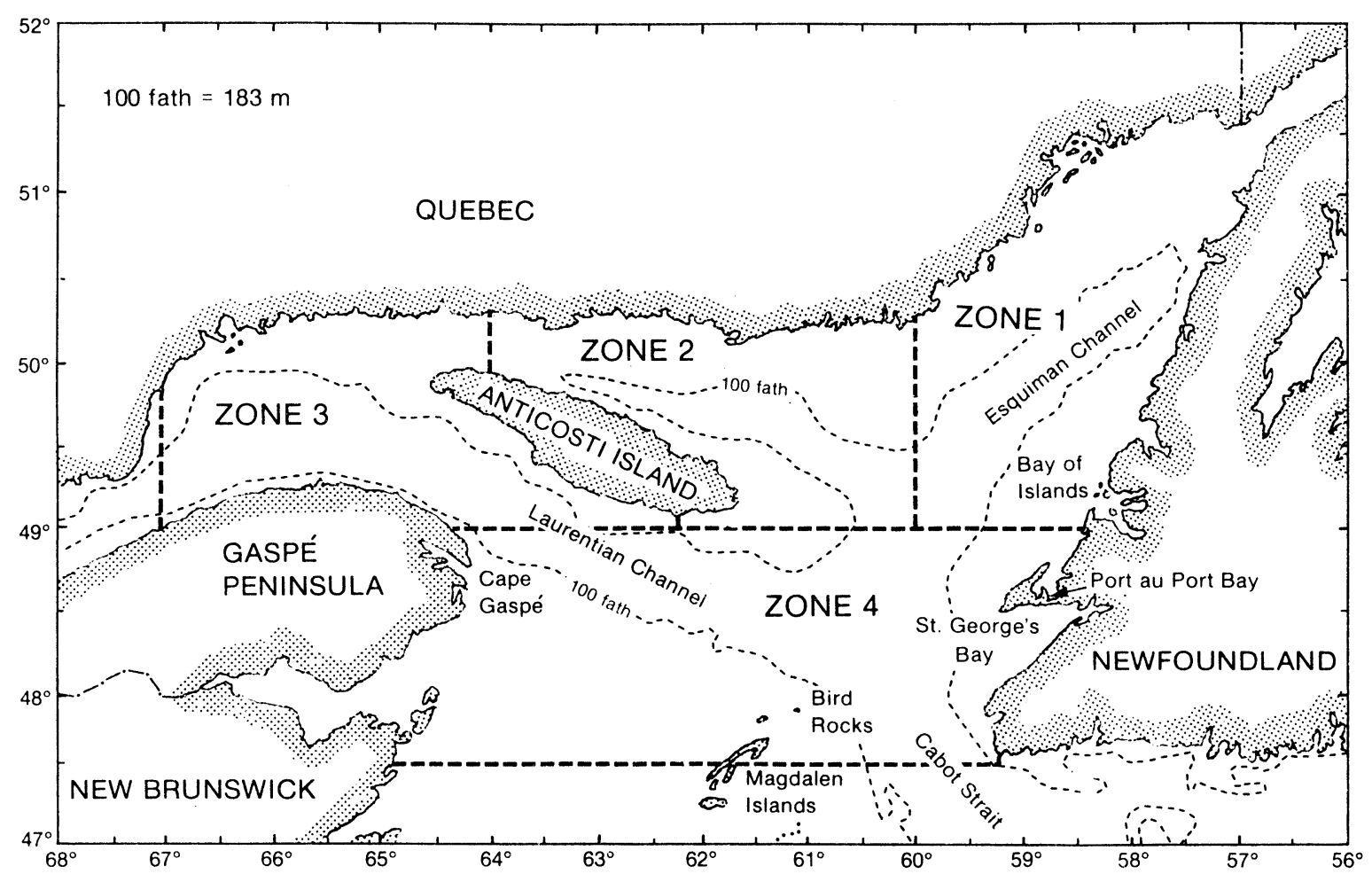

Fig. 1. The Gulf of St. Lawrence showing NAFO divisions and place names mentioned in the text. (Dashed lines are the boundaries of the four zones noted in Table 2.)

TABLE 1. General information on research vessels and surveys in the Gulf of St. Lawrence, 1976-81.

\begin{tabular}{lcccc}
\hline \hline & Beothic Venture & Vicki \& Brothers & A. T. Cameron & Gadus Atlantica \\
\hline Vessel overall length & $22 \mathrm{~m}$ & $26 \mathrm{~m}$ & $56 \mathrm{~m}$ & $80 \mathrm{~m}$ \\
Otter-trawl type & Yankee No. $36^{\mathrm{a}}$ & Yankee No. $36^{\mathrm{a}}$ & Yankee No. 41.5 & Engels high-rise \\
Effective codend mesh & $13 \mathrm{~mm}$ & $13 \mathrm{~mm}$ & $32 \mathrm{~mm}$ & $32 \mathrm{~mm}$ \\
Time of surveys & Summer (Jul-Aug) & Summer (Aug) & Autumn (Sep-Oct) & Winter (Jan-Feb) \\
Fishing hours & Daylight & Daylight & Day and night & Day and night \\
Number of tows -1976 & 110 & - & - & - \\
& - & - & 49 & - \\
1977 & 120 & - & 66 & 107 \\
1978 & 112 & - & 43 & 125 \\
1979 & 161 & 134 & - & 134 \\
\hline
\end{tabular}

a Modified for catching shrimp with $38 \mathrm{~mm}$ mesh size throughout.

At each fishing station, the redfish catch was quantified by weight and number and fish sizes were recorded as fork length to the nearest centimeter. During this process, golden redfish, (S. marinus) which are not considered in this paper, were separated from beaked redfish. Analysis of the redfish data involved separation of the length frequencies into two size categories termed "small" $(\leqslant 25 \mathrm{~cm})$ and "large" $(>25 \mathrm{~cm})$ in this paper. This dividing size was used because it has been considered traditionally as an appropriate reference size for the separation of sexually immature and mature redfish at approximate ages of 9-10 years.

Differences in trawls used during surveys in different seasons undoubtedly affected the total numbers of redfish caught as well as the relative proportions of small and large fish. However, catchability of a particular gear type was not expected to change from one area of the Gulf to another or from one year to the next. Consequently, to illustrate the spatial distribution of small and large redfish in each season, the survey data collected during 1976-81 were combined by season and average catches (numbers) per 30-min tow were calculated for each quadrangle of $30^{\prime}$ lat. and $60^{\prime}$ long. To illustrate temporal trends in size composition of the population by season, the catch length frequencies for each survey were weighted by the size of the appropriate depth strata and standardized to number per 1,000 fish.

The relationship between catch and depth in each of the three seasons was examined by assigning each 
catch of small and large redfish to one of seven depth intervals ( $\leqslant 140 \mathrm{~m}, 141-180 \mathrm{~m}, 181-220 \mathrm{~m}, 221-260 \mathrm{~m}$, 261-300 m, 301-340 $\mathrm{m}$ and $>340 \mathrm{~m}$ ) and calculating mean numbers per 30-min set over the 4-5 year periods pertinent to the seasonal surveys. Similarly, the relationship between catch and temperature was examined by using seven temperature ranges $\left(\leqslant 1.0^{\circ}\right.$, $1.1-2.0^{\circ}, 2.1-3.0^{\circ}, 3.1-4.0^{\circ}, 4.1-5.0^{\circ}, 5.1-6.0^{\circ}$ and $>6^{\circ} \mathrm{C}$ ). No temperature data were available for the summer survey in 1980, and consequently the mean catches pertain to four surveys for this comparison. Statistical analyses were attempted to test the null hypothesis that no differences existed in the relationship between catch per tow and depth or temperature, but these were not considered feasible in view of the great variation in sample size and widespread heterogeneity and non-normality of variances.

\section{Results}

\section{Seasonal distribution}

From the summer surveys in 1976 and 1978-81, small redfish $(\leqslant 25 \mathrm{~cm}$ ) were found to be distributed throughout the Gulf of St. Lawrence (Fig. 2A). The largest average catches ( $>4,000$ fish per set) occurred in the northern part of the Esquiman Channel, and catches exceeding 2,000 fish per tow occurred off Port au Port Bay and Bay of Islands, Newfoundland, and in various quadrangles south and east of Anticosti Island. Large redfish $(>25 \mathrm{~cm})$, although much less abundant than the small ones, were also present in variable quantities throughout the Gulf in summer, the main centers of concentration being in the deepwater area extending eastward from Anticosti Island to St. George's Bay
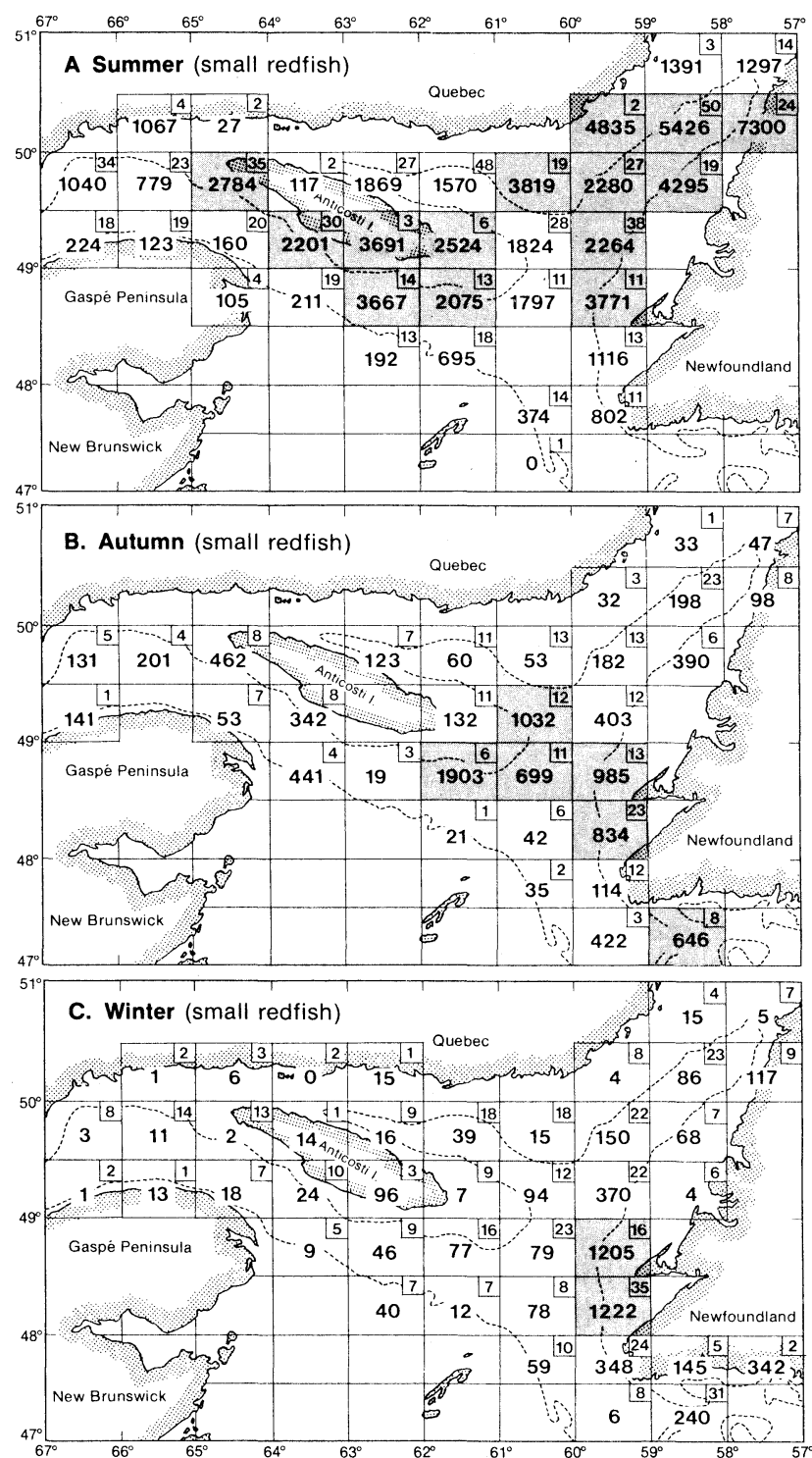
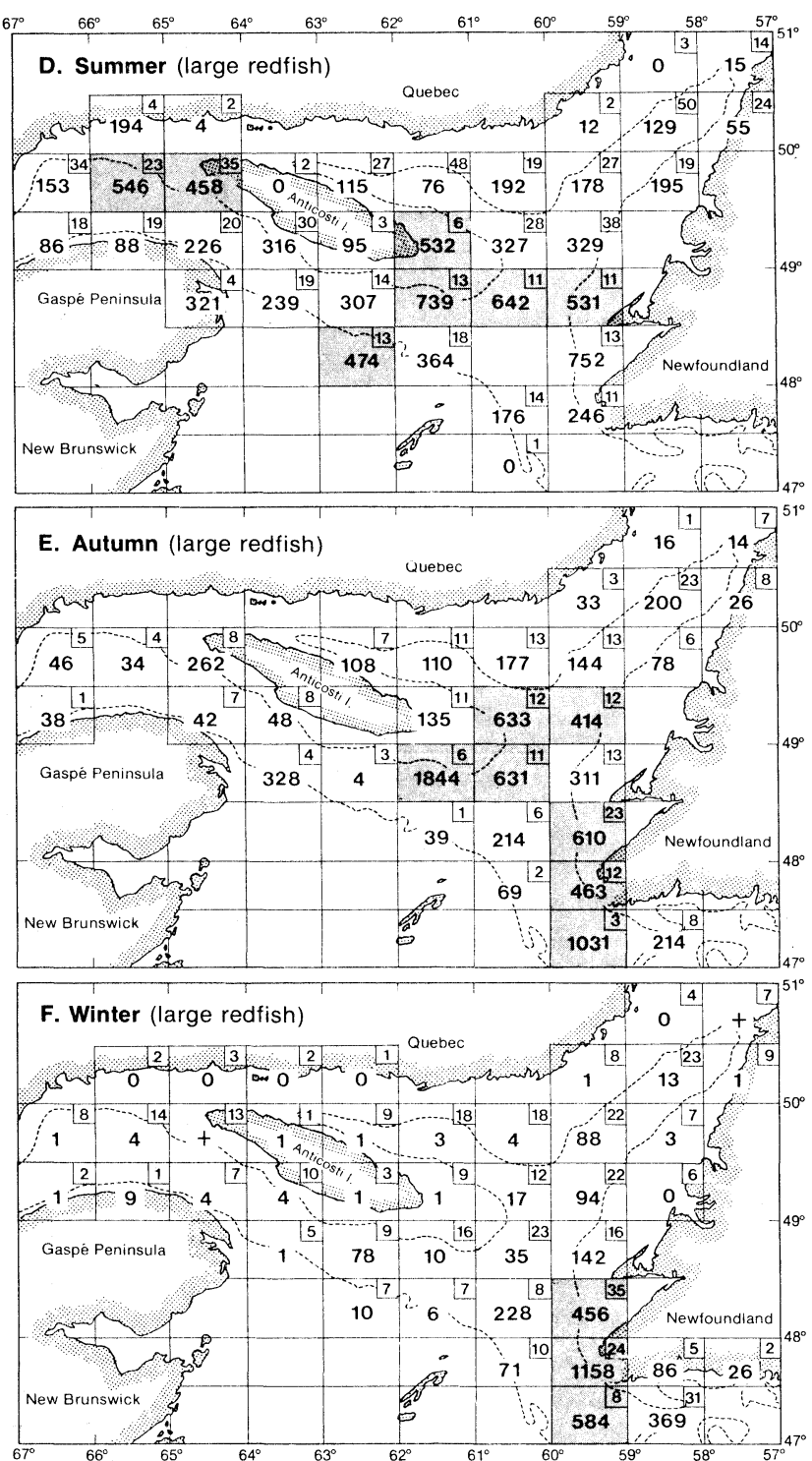

Fig. 2. Distribution of small and large redfish (mean number per tow) in the Gulf of St. Lawrence from (A, D) summer surveys in 1976, 1978-81, (B, E) autumn surveys in 1977-80, and (C, F) winter surveys in 1978-81. (Number of tows in the upper right corner of each quadrangle.) 
and in the Laurentian Channel west of Anticosti Island (Fig. 2D). Large redfish were not particularly abundant in the northeastern part of the Gulf where the largest catches of small redfish were obtained.

The autumn surveys in 1977-80 (Fig. 2B, E) did not cover the same quadrangles in all years nor was the coverage as good as that in summer due to unfavorable weather conditions. As was evident during the summer surveys, small redfish were still found throughout the surveyed area in the autumn of all years, but there was a significant change in distribution. The largest catches occurred in the region between the eastern end of Anticosti Island and western Newfoundland south of Bay of Islands, and catches were much smaller in the western and northeastern Gulf regions where small redfish were abundant in summer. Large redfish were concentrated in the same general area as the small fish and also southward from St. George's Bay to Cabot Strait. Their abundance west of Anticosti Island was evidently much lower in autumn than in summer.

The winter surveys in 1978-81 (Fig. 2C, F) were generally affected by ice conditions and the coverage varied from year to year. Nevertheless, the available observations indicate the scarcity of both small and large redfish in the western and northern parts of the Gulf and their concentration off southwestern Newfoundland. The small redfish tended to occupy the northern part of the overwintering area off Port au Port Bay and St. George's Bay, and the large fish were concentrated from St. George's Bay southward to Cabot Strait.

Athough these surveys were conducted by different vessels with different trawls and the coverage varied from season to season and year to year, the results indicate a definite movement of redfish from their summer-feeding grounds in the northern half of the Gulf to an overwintering area in the Laurentian Channel off southeastern Newfoundland. The summer concentrations of small redfish in the northeastern Gulf and of both small and large redfish around Anticosti Island had virtually disappeared at the time of the winter surveys.

\section{Length distributions}

The length distributions of redfish in the Gulf of St. Lawrence (Fig. 3) show the progression of successful year-classes of the early 1970's. The summer survey of 1976 revealed the presence of a strong year-class (probably 1974) with modal length of $10-11 \mathrm{~cm}$. This year-class occurred mainly in the northeastern part of the Gulf (Zone 1) in the summer of 1976 (Table 2) but was found to be dispersed throughout the Gulf in subsequent summer surveys (1978-79), with the greatest concentrations of small fish in Zones 3 and 4 . The summer and autumn surveys after 1976 (Fig. 3) indi-
TABLE 2. Percentages of small redfish $(\leqslant 25 \mathrm{~cm})$ by zone in the Gulf of St. Lawrence based on population numbers estimated from stratified-random trawl surveys in summer, 1976 and $1978-81$.

\begin{tabular}{crrrrr}
\hline \hline Zone & 1976 & 1978 & 1979 & 1980 & 1981 \\
\hline 1 & 72.4 & 29.7 & 14.9 & 20.4 & 58.3 \\
2 & 17.2 & 19.6 & 4.5 & 12.7 & 16.9 \\
3 & 5.2 & 21.8 & 37.2 & 43.5 & 14.5 \\
4 & 5.2 & 29.9 & 43.4 & 23.4 & 10.3 \\
\hline
\end{tabular}

cated that this year-class declined rapidly in abundance relative to the adjacent modal group of larger fish, but it remained relatively important during the winter surveys of 1978-81, when most of the redfish were concentrated off southeastern Newfoundland.

The summer and winter surveys of 1981 (Fig. 3) revealed the presence of another relatively strong year-class (probably 1980) with modal lengths of $7 \mathrm{~cm}$ in winter and $9 \mathrm{~cm}$ in summer. Associated with the appearance of this year-class was another increase in abundance of small redfish in Zone 1 in 1981 (Table 2), confirming the importance of the northern Esquiman Channel as a nursery area for redfish during the first year or two of their life. It is obvious that the shrimp trawl used during the summer surveys caught a greater proportion of small redfish than the otter trawls used for the autumn and winter surveys. The large redfish $(>30 \mathrm{~cm})$ that were apparent during the autumn and winter surveys represent the very strong year-classes of 1956 and 1958.

\section{Distribution by depth and temperature}

During the summer surveys (Fig. 4A), small redfish were concentrated primarily in depths of 181-260 m, whereas the large fish were found mainly in 221-300 m but also in quantity at greater depths. During the autumn surveys (Fig. 4B), small redfish were found over a wider depth range than in summer, being fairly evenly distributed over four depth intervals (181$340 \mathrm{~m}$ ), whereas the catches of large fish exhibited a bimodal distribution with the largest concentration in 301-340 $\mathrm{m}$. The changes in distribution from summer to autumn indicate movement of both small and large redfish to deeper areas. The winter surveys (Fig. 4C) show an intensification of concentration of large redfish in deepwater areas with greatest abundance at depths greater than $300 \mathrm{~m}$. Small redfish, on the other hand, were concentrated mainly shallower in 181$220 \mathrm{~m}$. These changes in depth distribution of small redfish are reflected in their migration from summer feeding grounds in the western and northeastern parts of the Gulf through the deep channels to shallower water off the southern part of western Newfoundland (Fig. 2).

Both small and large redfish were found over a wide range of bottom temperatures (Fig. 5A). The 


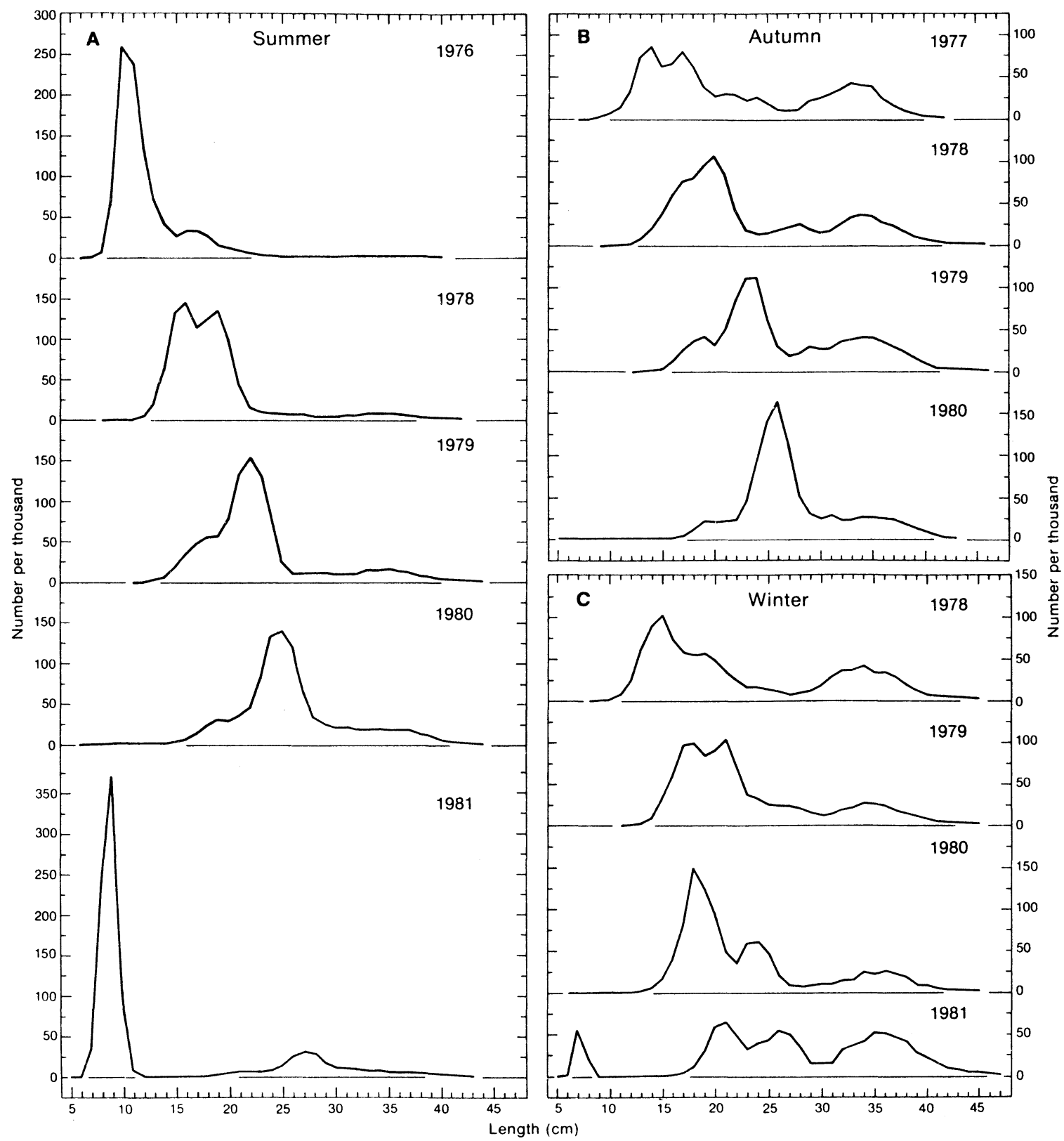

Fig. 3. Length distributions of redfish in the Gulf of St. Lawrence from (A) summer, (B) autumn, and (C) winter surveys during 1976-81.

mode at $2.1^{\circ}$ to $3.0^{\circ} \mathrm{C}$ for small redfish was mainly due to the catch in 1976 of large numbers of juveniles (Fig. $3 A)$ in relatively shallower depths in the northeastern area of the Gulf (Fig. 2A). In the autumn (Fig. 5B), both small and large redfish preferred temperatures higher than $4.0^{\circ} \mathrm{C}$, with greatest abundance where temperatures exceeded $6.0^{\circ} \mathrm{C}$, and this pattern was even more pronounced in winter (Fig. $5 \mathrm{C}$ ) when about $70 \%$ of both small and large fish were taken in areas where temperatures exceeded this value (averages of $6.7^{\circ}$ and $6.8^{\circ} \mathrm{C}$ for small and large fish respectively).

Although average bottom temperatures during the autumn surveys were slightly lower at shallower depths than those recorded during the summer and winter surveys, the overall patterns were quite similar in the three seasons (Fig. 6).

\section{Discussion}

The existence of redfish concentrations off the south coast of Anticosti Island has been well documented (Steele, 1957; Bergeron, 1961; Kohler, MS 1968). The summer and autumn surveys of 1976-81 also showed that small and large redfish were concentrated in that region, indicating preferred environmental conditions of long standing. Also, the persistence of 


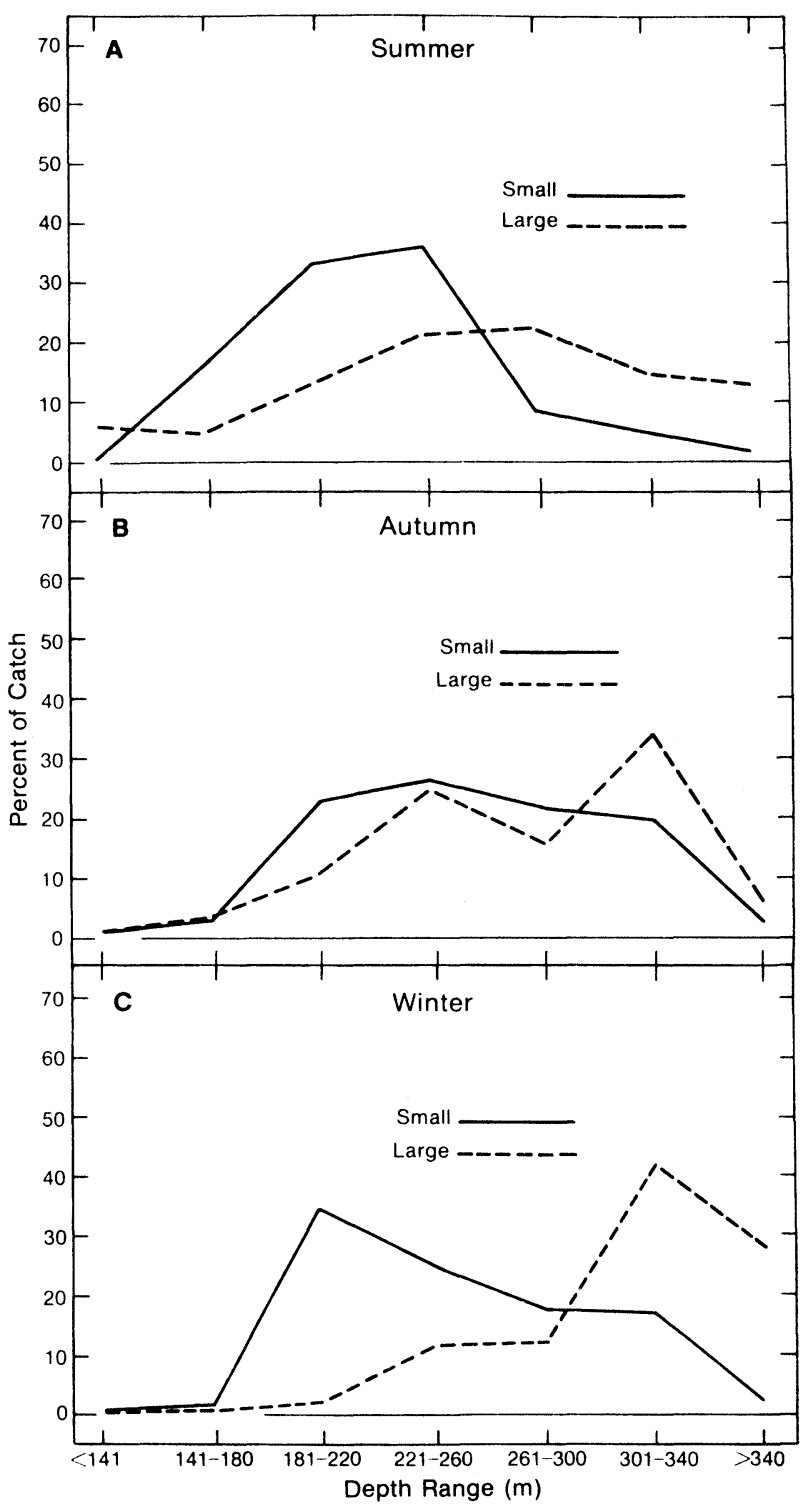

Fig. 4. Distribution of small and large redfish by depth interval in the Gulf of St. Lawrence from (A) summer surveys in 1976 and 1978-81, (B) autumn surveys in 1977-80, and (C) winter surveys in 1978-81.

redfish concentrations off Cape Gaspè and Bird Rocks, as reported by Kohler (MS 1968) and Koeller and LeGresely (MS 1981), was confirmed in the present study, but the recent catches in these areas consisted mainly of large fish in contrast to the relatively higher abundance of small fish in other areas of the Gulf, particularly in summer.

During sporadic surveys of the Gulf of St. Lawrence in the 1960's, small redfish were found in the summer of certain years at various locations in the Gulf (north of Anticosti Island, off Cape Gaspè, off Bay of Islands, and in northern Esquiman Channel), but the strongest year-classes were located primarily in the last two areas (unpubl. cruise reports, Biological Sta-

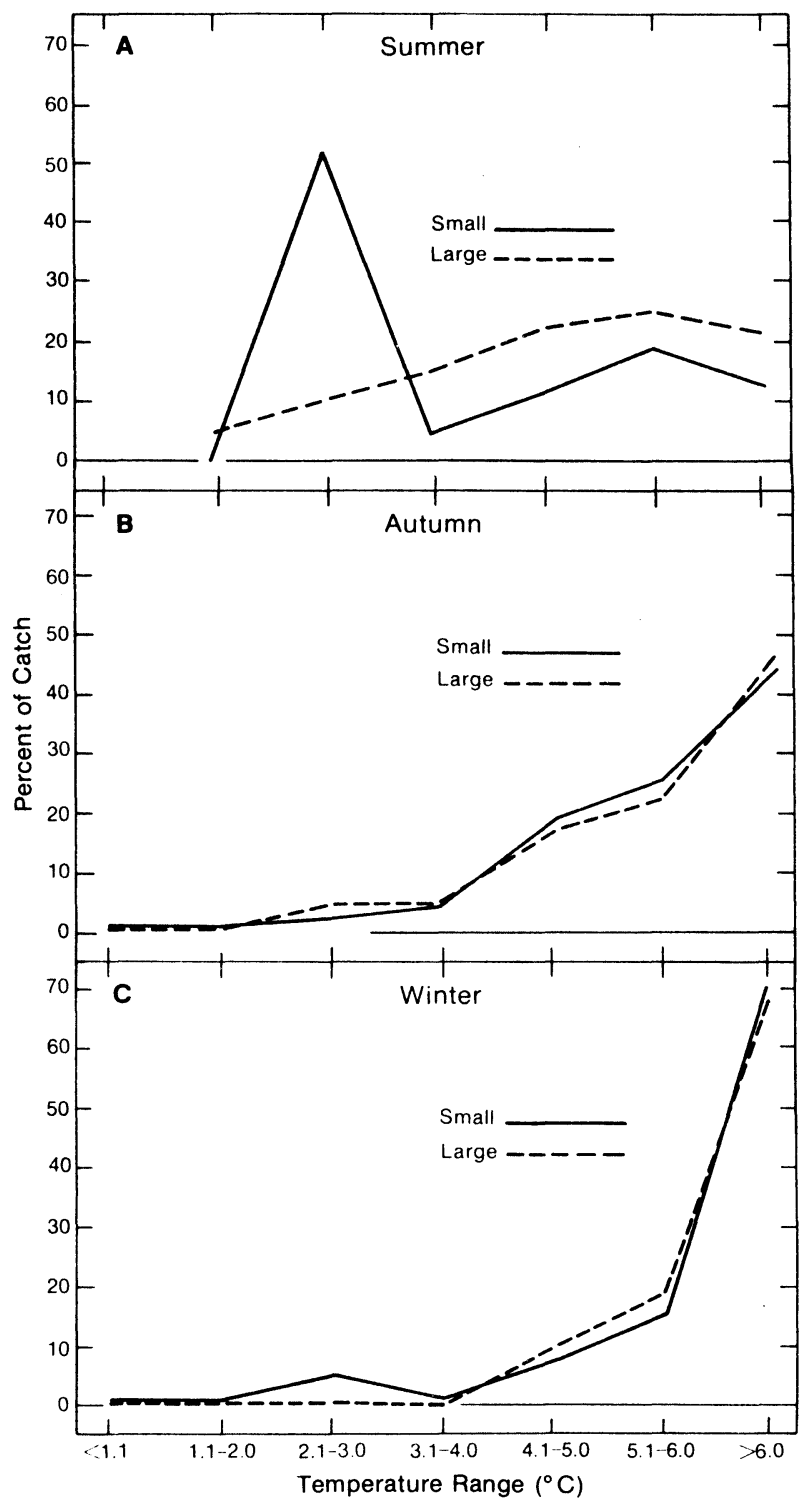

Fig. 5. Distribution of small and large redfish relative to bottom temperature in the Gulf of St. Lawrence from (A) summer surveys in 1976-1978-81, (B) autumn surveys in 1977-80, and (C) winter surveys in 1978-81.

tion, St. John's, Nfld.). The results of the summer surveys in 1976 and 1978 indicate that, when large numbers of small juveniles were present in the Gulf (Fig. 3A), they were found predominantly in the Esquiman Channel, which is considered to be the primary nursery area.

The concentration of redfish in the southeastern region of the Gulf in winter, as shown by the results of surveys during January-February in 1978-81, indicates that this species undergoes extensive seasonal migrations. This type of movement from the northern Gulf to overwintering areas in Cabot Strait or outside the Gulf has been reported for Atlantic cod (Gadus morhua) by Templeman $(1962,1974,1979)$ and Minet 


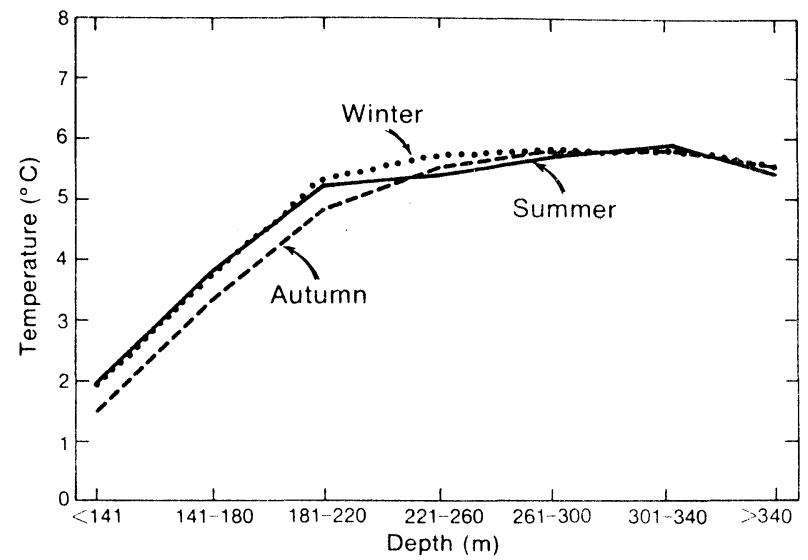

Fig. 6. Changes in average bottom temperature with depth, from the summer, autumn and winter surveys of the Gulf of St. Lawrence during 1976-81.

(1978), for Greenland halibut (Reinhardtius hippoglossoides) by Bowering (1982), and for witch flounder (Glyptocephalus cynoglossus) by Bowering and Brodie (1984). The formation of dense concentrations of redfish in deep water along the northern edge of the Laurentian Channel at the entrance to the Gulf in winter is well known to trawler fishermen. This movement of redfish to the Cabot Strait area is not restricted to large (mature) fish (Fig. 2C). However, there is some indication that most of the small redfish overwinter just inside the Gulf off Port au Port Bay and St. George's Bay.

Koeller and LeGresley (MS 1981) regarded the redfish along the southern slope of the Laurentian Channel from Cape Gaspè to the Bird Rocks and southeastward in Cabot Strait (Fig. 1) as a separate stock. Although survey coverage of this part of the Gulf was not as good in autumn and winter as the coverage of other areas, there are indications that these fish also overwinter in the Cabot Strait area. Whether these fish remain on the southern slope of the Laurentian Channel in the Cabot Strait area or mix with those overwintering on the northern slope off southwestern Newfoundland is unknown at present, but the depth of the Channel $(450-500 \mathrm{~m})$ is not a restrictive barrier for redfish (Templeman, 1959). Sandeman (MS 1973) regarded the redfish in the Gulf of St. Lawrence as a single stock.

There is some indication that both small and large redfish begin their migration toward the southeastern part of the Gulf in late summer or early autumn (Fig. 2). Examination of data from the individual winter surveys, two of which occurred in January and two in February, indicates that migration may be still taking place in January, because redfish were less concentrated in the overwintering areas in January than in February. Occasional surveys of parts of the Gulf in the late 1950's and early 1960's were usually made in
November and redfish were generally found in all areas surveyed (unpubl. cruise reports, Biological Station, St. John's, Nfld.), although relative distributions cannot be determined from these data. An indication of the time of dispersal of redfish throughout the Gulf cannot be obtained from the data presented in this paper. However, during a survey in May 1967, the largest catches of redfish were obtained in the southeastern part of the Gulf. Very few redfish were caught in the northern part of the Gulf, and, because the echosounder records showed no evidence of pelagic concentrations of fish, redfish were assumed to emigrate from the Gulf in winter and return possibly in June. Steele (1957), from investigations off Cape Gaspe in the western Gulf, reported that the average catch per tow increased substantially from June to October 1953 and that catches were again small when fishing was resumed in May 1954.

During the summer and autumn surveys in 1976-81, redfish were found mainly in depths of 181$340 \mathrm{~m}$. This is consistent with the findings of other researchers from more restricted areas of the Gulf (Steele, 1957; Templeman, 1959; Bergeron, 1961). During the winter surveys in 1978-81, small redfish were found in approximately the same depth range as in summer and autumn (181-300 m), but the large fish moved deeper and were most abundant in depths exceeding $300 \mathrm{~m}$. That the small redfish were generally found shallower than the large fish is not surprising, because stratification of redfish size by depth is a wellknown phenomenon (Perlmutter, 1953; Schroeder, 1955; Templeman, 1955, 1957, 1959). The indication from the 1976-81 surveys that redfish tend to be deeper in winter than in summer was inferred also by Templeman and Pitt (1961) from their examination of data reported by Travin (1959) for the Northwest Atlantic.

From summer surveys in the Gulf of St. Lawrence, Templeman (1959) reported that redfish were found mainly in areas where temperatures were between $3^{\circ}$ and $5^{\circ} \mathrm{C}$ and that temperatures of the deepwater layer were usually not higher than $5.5^{\circ} \mathrm{C}$. His observations were generally in agreement with those of Tåning (1949) for redfish in Greenland waters. Results from the summer, autumn and winter surveys in 1976-81 (preferred temperatures in the range of $2^{\circ}$ to $7^{\circ} \mathrm{C}$ ) support these earlier observations, although the maximum temperature was somewhat higher than during the time of Templeman's investigations. Trites (1972) indicated that temperatures below about $170 \mathrm{~m}$ in the Gulf remained quite constant and warm throughout the year, and Budgen (1981) noted that the warm deepwater layer below $100 \mathrm{~m}$ has no resolvable seasonal cycle and only undergoes longer term changes. Therefore, the movement of large redfish to deeper water and their migration from the western and northern parts of the Gulf cannot be attributed to cooling of the deepwater layer. 
The winter concentrations of large redfish at the entrance to the Gulf are unlikely to represent premating aggregations, because copulation presumably occurs in the autumn. According to Steele (1957), gonad development in Gulf redfish fit the pattern described for redfish in Northeast Atlantic waters where mating occurs during October-January (Magnusson, 1955) or August-October (Sorokin, 1961). Also, the concentrations are not necessarily preextrusion aggregations, as occurs in European waters (Sorokin, 1961), because the larvae are not released until MayJuly (Steele, 1957), when the redfish are dispersing throughout the Gulf. In fact, the presence of early stage redfish larvae throughout most of the Gulf (Frost, 1938; Steele, 1957; Templeman, 1959; Day, 1961) indicates that the adults are widely dispersed at the time of larval release.

According to Sandeman (MS 1973) from observations during the 1950's and 1960's, year-class strength of redfish in the Gulf of St. Lawrence fluctuates greatly. If larvae are extruded when the adults are concentrated in the Laurentian Channel from Cape Gaspè to Cabot Strait, the eastward flow of the Gaspè Current would eventually carry them out of the Gulf, resulting in poor year-classes (Templeman, 1959). Infrequently, the dispersion of redfish to the northern Gulf areas may be earlier than usual or the extrusion of larvae may be delayed. In either case, the chances of larval survival are greatly improved if extrusion occurs in the northern part of Esquiman Channel, which apparently is the main nursery area for small redfish. Extensive surveys of the Gulf in spring and early summer for several years would be required to determine if variation in the dispersal and distribution of adults are associated with year-class success and failure.

\section{Acknowledgements}

I acknowledge the valuable assistance of C. A. Gavaris for attempts at statistical analysis and comments during the preparation of this paper, and I thank W. D. Bowen and G. R. Lilly for their reviews of the manuscript.

\section{References}

ATKINSON, D. B. 1984. Discarding of small redfish in the shrimp off Port au Choix, Newfoundland, 1976-80. J. Northw. Atl. Fish. Sci., 5: 99-102.

BERGERON, J. 1961. Redfish explorations in the Gulf of St. Lawrence, 1957. ICNAF Spec. Publ., 3: 122-123.

BOWERING, W. R. 1982. Population dynamics of Greenland halibut in the Gulf of St. Lawrence. J. Northw. Atl. Fish. Sci., 3: 141-147.

BOWERING, W. R., and W. B. BRODIE. 1984. Distribution of witch flounder in the northern Gulf of St. Lawrence and changes its growth and sexual maturity patterns. N. Am. J. Fish. Mgt., 4: (in press).
BUGDEN, G. L. 1981. Salt and heat budgets for the Gulf of St. Lawrence. Can. J. Fish. Aquat. Sci., 38: 1153-1167.

DAY, L. R. 1961. Summer surface distribution of redfish larvae in ICNAF Subarea 4, 1954-1955. ICNAF Spec. Publ., 3: 195-198.

DOUBLEDAY, W. G. (ed.). 1981. Manual on groundfish surveys in the Northwest Atlantic. NAFO Sci. Coun. Studies, 2: $55 \mathrm{p}$

FROST, N. 1938. Some fishes of Newfoundland waters, with notes on distribution of eggs and larvae. Res. Bull. Dept. Natural Resources, Nfld., 4: $116 \mathrm{p}$.

ICNAF. 1957-80. Fishery statistics for the Northwest Atlantic. ICNAF Stat. Bull., Vol. 5-28.

KOELLER, P. A., and M. LEGRESELY. MS 1981. Abundance and distribution of finfish and squid from $E$. E. Prince trawl surveys in the southern Gulf of St. Lawrence, 1970-79. Can. Tech. Rep. Fish. Aquat. Sci., No. 1028, 56 p.

KOHLER, A. C. MS 1968. Fish stocks of the Nova Scotia banks and Gulf of St. Lawrence. Fish. Res. Board Can. Tech. Rep., No. 80, 25 p.

MAGNÛSSON, J. 1955. Mikroskopisch-anatomische Untersuchungen zur Fortpfanzungsbiologie des Rotbarsches (Sebastes marinus L.) Z. Zellforsch., 43: 121-167. (Fish Res. Board Can. Transl. Ser., No. 138, 1958.)

MARTIN, W. R. 1961. The distribution of redfish catches landed on the southern Canadian mainland, 1949-1958. ICNAF Spec. Publ., 3; 148-153.

MINET, J.P. 1978. Dynamics and yield assessment of the northeastern Gulf of St. Lawrence cod stock: ICNAF Sel. Papers, 3: 7-16.

NI, I-H. 1981. Separation of sharp-beaked redfish, Sebastes fasciatus and S. mentella from northeastern Grand Bank by morphology of extrinsic gasbladder musculature. J. Northw. Atl. Fish. Sci., 2: $7-12$.

1982. Meristic variation in beaked redfishes, Sebastes mentella and $S$. fasciatus, in the Northwest Atlantic. Can. J. Fish. Aquat. Sci., 39: 1664-1685.

NI, I-H., and W. D. McKONE. 1983. Distribution and concentration of redfishes in Newfoundland and Labrador waters. NAFO Sci. Coun. Studies, 6: 7-14

PAYNE, R. H., and I-H. NI. 1982. Biochemical population genetics of redfishes (Sebastes) off Newfoundland. J. Northw. Atl. Fish. Sci., 3: $169-172$.

PERLMUTTER, A. 1953. Population studies of the rosefish. Trans. N. Y. Acad. Sci., Ser. 2, 15(5): 189-191.

SANDEMAN, E. J. MS 1973. The redfish fishery in the Gulf of St. Lawrence: biological considerations - past, present and future? Can. Fish. Mar. Serv., St. John's Biol. Sta. Circ., No. 20, 19 p.

SCHROEDER, W. C. 1955. Report on the results of exploratory ottertrawling along the continental shelf and slope between Nova Scotia and Virginia during the summers of 1952-1953. Deep-Sea Res., Suppl. to Vol. 3: 358-372.

SOROKIN, V. P. 1961. The redfish, gametogenesis and migrations of the Sebastes marinus (L.) and Sebastes mentella Travin. ICNAF Spec. Publ., 3: 245-250.

STEELE, D. H. 1957. The redfish (Sebastes marinus L.) in the western Gulf of St. Lawrence. J. Fish. Res. Board Can., 14: 899-924.

TÅNING, A. V. 1949. On the breeding places and abundance of the redfish (Sebastes) in the North Atlantic. ICES J. Cons., 16: 85-95.

TEMPLEMAN, W. 1955. Summary of Canadian researches, 1954, Subareas 2 and 3. ICNAF Ann. Proc., 5: 19-20.

1957. Redfish exploration north of Flemish Cap. Fish. Res. Board Can., Atlant. Prog. Rep., 67: 14-18.

1959. Redfish distribution in the North Atlantic. Bull. Fish. Res. Board Can., 120, $173 \mathrm{p}$.

1962. Divisions of cod stocks in the Northwest Atlantic. ICNAF Redbook, 1962(III): 79-123.

1974. Migrations and intermingling of Atlantic cod, Gadus morhua, stocks of the Newfoundland area. J. Fish. Res. Board Can., 31: 1073-1092.

1979. Migration and intermingling of stocks of Atlantic cod, Gadus morhua, of Newfoundland and adjacent areas from tagging in 1962-66. ICNAF Res. Bull., 14: 5-50.

TEMPLEMAN, W., and T. K. PITT. 1961. Vertebral numbers of redfish, Sebastes marinus (L.), in the Northwest Atlantic, 1947-1954. ICNAF Spec. Publ., 3: 56-89. 
TEMPLEMAN, W., and E. J. SANDEMAN. 1957. Two varieties of redfish in the Newfoundland area. Fish. Res. Board Can., Atlant. Prog. Rep., 66: 20-23.

TRAVIN, V. I. 1959. Union of Soviet Socialist Republics research report, 1958. ICNAF Ann. Proc. 9: 81-85.

TRITES, R. W. 1972. The Gulf of St. Lawrence from a pollution viewpoint. In Marine pollution and sea life, M. Ruivo (ed.), Fishing News (Books) Ltd., London, England, p. 59-72. 
